\title{
高性能パッシブ換気住宅における 木質バイオマスを用いたコミュニティ暖房システムの検討 A STUDY ON COMMUNITY HEATING SYSTEM USING WOODY BIOMASS FOR HIGH PERFORMANCE PASSIVE VENTILATION HOUSES
}

\author{
松尾悠佑*, 菊田弘輝**, 斉藤雅也 ${ }^{* * *}$, 羽山広文**** \\ Yusuke MATSUO, Koki KIKUTA, Masaya SAITO \\ and Hirofumi HAYAMA
}

\begin{abstract}
The purpose of this study is to clarify how to design high-efficiency "community heating system" using woody biomass which supplies thermal energy to a group of high performance passive ventilation houses. Annual heating demands of communities were calculated based on the insulation performance of houses and the living activities of households. Three kinds of community: new-region, mixed-region, and old-region were assumed from the combinations of three different insulation levels of houses. On the other hand, supply side system on the analytical model consist of biomass boilers, pumps and pipes. From the results of analysis in the case of 20 to 100 houses, SCOP is highest in new-region, followed in order by mixed-region and old-region. SCOP in all cases of community heating system is higher than that of individual heating system. Total input exergy for the community heating system in case of 40 houses is 1.1 to 1.4 times larger than that for individual heating system. However, $72 \%$ of this input exergy of the community heating system is equivalent to the chemical exergy within woody biomass which can be obtained in the neighborhood.
\end{abstract}

Keywords : Community heating system, Passive ventilation house, Woody biomass, Exergy, Living activities コミュニティ暖房システム, パッシブ換気住宅，木質バイオマス，エクセルギー，生活スケジュール

\section{1. はじめに}

積雪寒冷地である北海道では暖房エネルギー使用量の削減が重要 であり，住宅の断熱・気密性能の向上に伴い，高性能住宅に対応し た暖房システムの構築が求められている。中でもパッシブ換気住宅 は高断熱・高気密を前提とし，建物内外の温度差による自然換気を 行う住宅で，寒冷地の特徴を活かした技術と言える ${ }^{1)}$ 。

同時に近年，全国的に再生可能エネルギーの導入が推進されてお り，特に我が国の森林資源の賦存量は大きいことから，木質バイオ マスの有効利用が推奨されている。木質バイオマスの高性能住宅一 の導入では, 様々な試みが行われており, 薪ストーブやペレットス トーブを用いた事例が多く見られる。筆者らは既報2) で薪ストーブ 1台によって全室暖房を行う高性能パッシブ換気住宅を対象として 実測を行い，快適な温熱・空気環境の形成を確認した上で，エネル ギー・エクセルギー解析から温熱環境の形成機構を明らかにした。

一方，オーストリアなどの欧州では環境対策に加えて農家の新た な事業創出という側面から, 山間地域でバイオマス熱供給システム の導入が急速に進んでいる。これらは導管延長 $100 \sim 300 \mathrm{~m}$ 程度, ボイラー出力 $50 \sim 300 \mathrm{~kW}$ 程度と小規模であり, 熱導管の高断熱化
や配管ルートの検討によるシステムの適正化がなされつつある3) 11)。熱供給という形態をとることで, バイオマスボイラーやサイ 口などの大規模な設備を集約化できるとともに，一般の需要家(市 民)にとって手間の要する木質燃料を手軽に熱として享受すること ができるようになった。日本でも近年，一部の地域で木質バイオマ スを利用した小規模熱供給システムが導入されるようになり，地域 資源の活用や地域経済の活性化に加え, 地域のエネルギー自給・安 定供給の観点からも注目を集めている ${ }^{12)}$ １4)。

高性能住宅群への熱供給システム導入を想定すると, 更なる一次 エネルギー使用量の削減が期待されるが，地域の熱需要の大きさや 変動特性がシステム全体の効率に大きな影響を及ぼすため, 需要サ イドである住宅群の熱需要を正確に想定したうえで，供給サイドで ある熱源・搬送システムを計画していくことが重要である。

本研究では, 数十件の世帯がコンパクトな熱源を共有して暖房を 行うシステムを「コミュニティ暖房システム」と定義し，高性能 パッシブ換気住宅を含む住宅群を対象として, 木質バイオマスを導 入した際のシステム検証を行う。その際に，地域の熱需要は一般的 に原単位 $\left[\mathrm{MJ} / \mathrm{m}^{2}\right.$ ・year $]$ を用いて想定されることが多いが，本研究
* (株)日本設計

** 北海道大学大学院工学研究院 助教 $\cdot$ 博士 (工学)

*** 札幌市立大学デザイン学部 准教授・博士 (工学

**** 北海道大学大学院工学研究院 教授. 博士 (工学)
Nihon Sekkei, Inc.

Assist. Prof., Faculty of Eng., Hokkaido Univ., Dr.Eng.

Assoc. Prof., School of Design, Sapporo City Univ., Dr.Eng.

Prof., Faculty of Eng., Hokkaido Univ., Dr.Eng. 
では，住宅の断熱性能や地域を構成する各世帯の生活パターンを考 慮して地域の熱需要を作成する。これにより，需要サイドと供給サ イドの両面からの検証を可能とし, 特に, 地域の世帯構成やコミュ ニティサイズがシステム効率に与える影響を明らかにする。その上 で, 個別暖房として空気熱源ヒートポンプ式温水暖房機を取り上 げ，一次エネルギー基準のシステム効率を比較する。また，木質バ イオマスと化石燃料の持つ資源性を同等に扱うことが可能なエクセ ルギー概念を導入し，システム全体のエクセルギー消費過程を比較 する。なお，本研究では高性能パッシブ換気住宅を含む住宅群を想 定するが，断熱性に応じた換気量を変更することで，一般的な機械 換気を採用した高性能住宅を含む住宅群を想定することもできる。

\section{2. 地域の熱需要}

\section{1 熱需要の構成要素}

本章ではコミュニティ暖房で熱の供給を受ける地域の熱需要を作 成する。住宅の断熱性能と居住者の生活パターンから世帯の熱需要 を想定し, それらを組み合わせて様々な世帯構成の地域の熱需要を 作成した。表 1 に熱需要の構成要素を示す。ここでは, 「個人」,

「世帯」,「地域」の3つのレイヤを設定する。個人は「属性」に よって8つに分類され，各属性ごとの生活スケジュールが決定す る。世帯は家族構成を表す「家族類型の群分類」と住宅性能を表す 「断熱レベル」の2つによって分類される。各家族類型の群分類ご との発熱スケジュール，各断熱レベルごとの断熱仕様に基づいて，

「世帯類型」を設定し，世帯の熱需要が決定する。地域は「地域類 型」によって分類され，地域の熱需要が決定する。

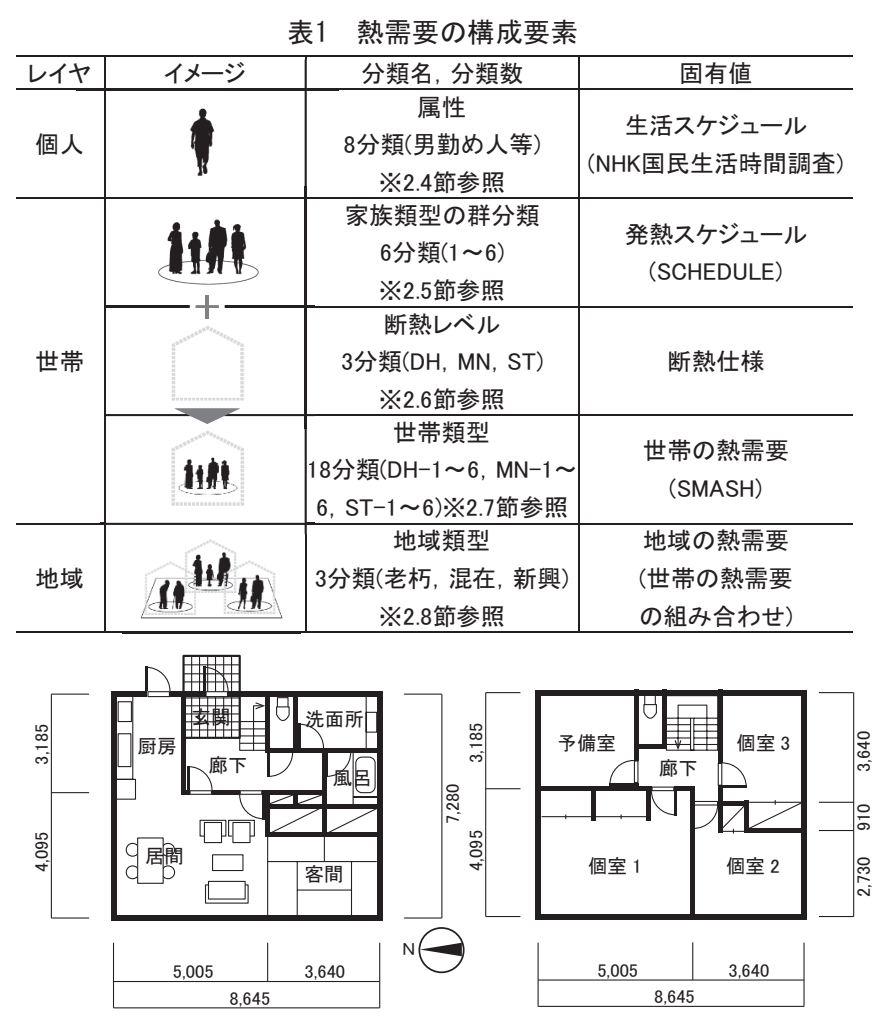

延べ床面積: $124.48 \mathrm{~m}^{2}$ (1階: $62.24 \mathrm{~m}^{2}, 2$ 階: $62.24 \mathrm{~m}^{2}$ ) 開口部比率: $8.0 \%$

隣棟間隔: $5 \mathrm{~m}$ (北面, 南面, 西面), $15 \mathrm{~m}$ (東面) 図1 住宅モデルの平面図

\section{2 対象地区}

コミュニティ暖房の対象地区は北海道月形町とする。特別豪雪地 帯に指定され，さらに，町の面積の約6割を森林が占めることか ら，木質バイオマスの十分な賦存量を有していると考えられる。

2.3 住宅・街区モデル

実際の地域には多様な住宅が存在するが，本研究では計算負荷の 低減のため, 同一の住宅モデルを用いた。一般的な用途の室を持つ ことや戸建住宅の平均的な延心床面積を考慮し, 日本建築学会の標 準住宅問題を採用する。図1に住宅モデルの平面図を示す。主な採 光面は西面である。また, 周辺環境は住宅の北面, 南面, 西面の隣 棟間隔を $5 \mathrm{~m}$ ，東面の道路を挟んだ建物との距離を $15 \mathrm{~m}$ とた。

\section{4 属性}

個人は「小学生」,「中学生」,「高校生」,「男勤め人」, 「女勤め人」,「主婦」,「男70歳以上」,「女70歳以上」の8つ の属性によって分類される。各属性について, NHK国民生活時間 調查 (2010年) を用い, 平日・休日の 15 分間隔の生活スケジュール を作成した注1)。図2に生活スケジュールの例(男勤め人)を示す。

\section{5 家族類型の群分類}

属性の組み合わせである家族類型のうち，代表的な 33 パターン の発熱スケジュールを『SCHEDULE Ver.2.1』を用いて作成した注 2)。図3に発熱スケジュールの例 (男勤め人十主婦十中学生十高校 生)を示す。平日，休日の平均発熱量はそれぞれ約 $0.50 \mathrm{kWh} / \mathrm{h}$, 約 $0.55 \mathrm{kWh} / \mathrm{h}$ ，最大発熱量は約 $2 \mathrm{kWh} / \mathrm{h} ，$ 約 $3 \mathrm{kWh} / \mathrm{h}$ であった。

図4に各家族類型の週積算発熱量と週積算在宅時間を示す。週積 算在宅時間は同一の家族形式で概㱛等しい一方で，週積算発熱量は
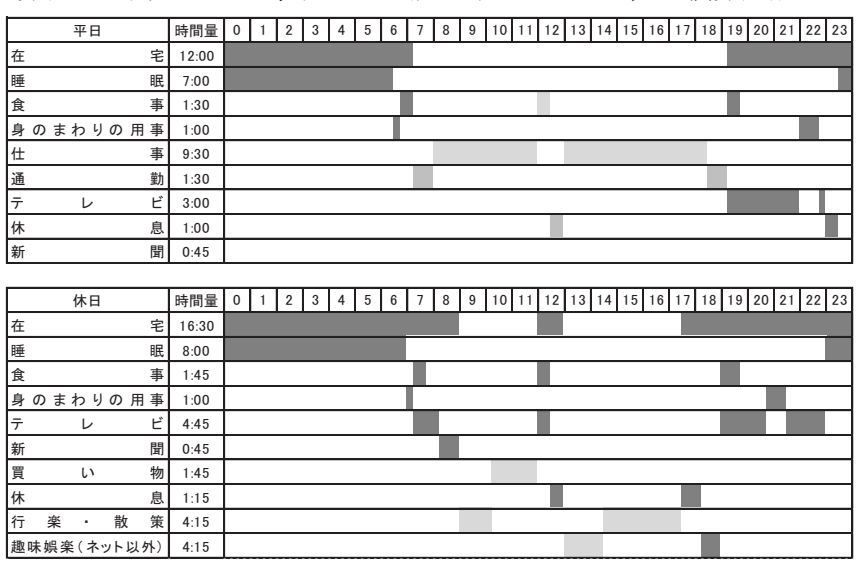

在宅非在宅

図2 生活スケジュールの例 (属性 : 男勤め人)

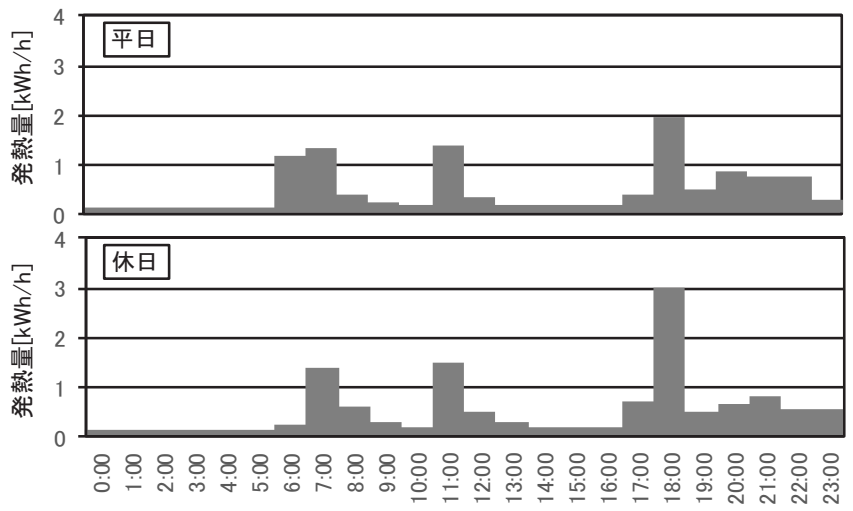

図3発熱スケジュールの例

(家族類型 : 男勤め人十主婦十中学生十高校生) 
同一の家族形式でも構成人数に応じて変動した。

図5に各家族類型の週積算発熱量と週積算在宅時間の関係を散布 図として示す。各家族類型を週積算発熱量, 週積算在宅時間の関係 から70,90kWh/weekの発熱量, 130h/weekの在宅時間を閾值とし て6つの群に分類した (家族類型の群分類)。また，各群分類から一 つずつ抽出した家族類型で代表させた注 3 )。

\section{6 断熱レベル}

住宅の断熱性能は「老朽住宅 (DH)」，「ミニマムレベル

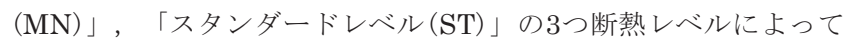
表される。表 2 に各断熱レベルの断熱仕様を示す。外壁の断熱仕様 はDHでグラスウール $(\mathrm{GW}) 100 \mathrm{~mm}, \mathrm{MN}$ で高性能グラスウール (HGW) $100 \mathrm{~mm} ， \mathrm{ST}$ で高性能グラスウール $200 \mathrm{~mm}$ である。位置づ けは，DHが築30年程度の断熱改修が必要なレベル，MNが改正省 エネ基準を満たす最低レベル，STが積雪寒冷地の標準レベルであ る。換気方式はDHを第3種換気とし，MN，STをパッシブ換気と した。暖房時間はDHを間欠暖房，MN，STを連続暖房とした。

\section{7 世帯類型}

世帯類型は家族類型の群分類と断熱レベルの組み合わせによって 表され，「DH-1〜6」，「MN-1〜6」，「ST-1〜6」（断熱レベル群分類)の全18パターンである。各世帯類型のもつ発熱スケジュー ルおよび住宅の断熱仕様から『住宅用熱負荷計算プログラム $\mathrm{SMASH}$ 』用いて熱需要を算出した。外気温は月形町の拡張アメ ダス気象データを用いた。また, 熱需要の平準化の程度を表す指標 として平準化率注4) を用いた。

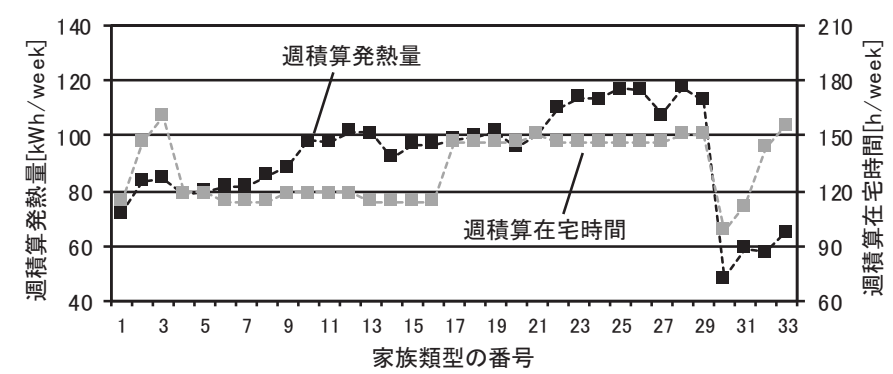

図4 各家族類型の発熱量と在宅時間

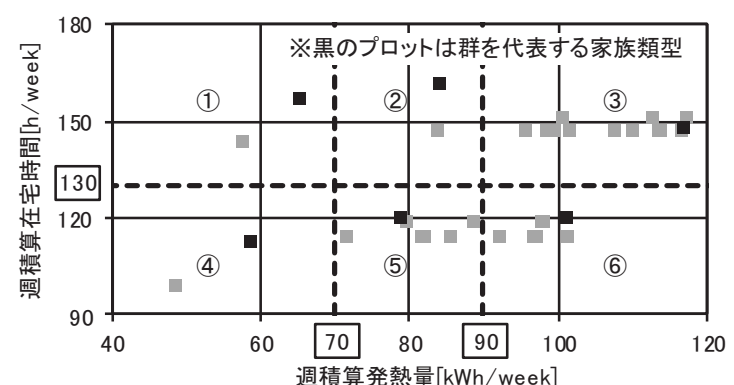

図5＼cjkstart各家族類型の発熱量と在宅時間の関係

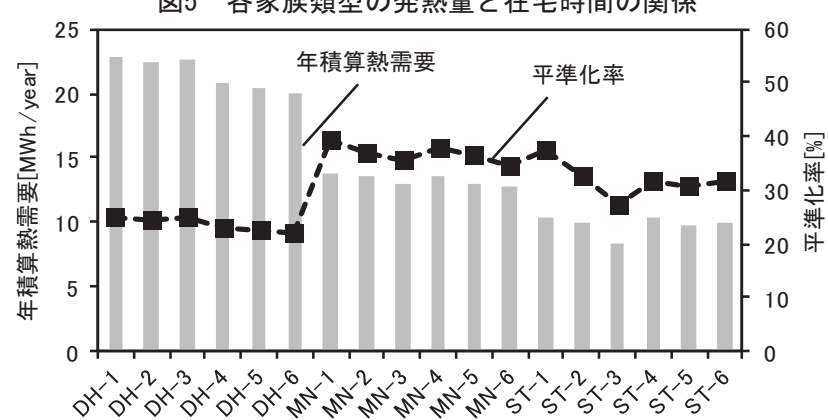

図6 各世帯類型の熱需要と平準化率

図6に各世帯類型の熱需要とその平準化率を示す。年積算熱需 要, 平準化率ともに断熱レベルに大きく依存し，年積算熱需要は $\mathrm{DH}>\mathrm{MN}>\mathrm{ST}$ ，平準化率は $\mathrm{MN}>\mathrm{ST}>\mathrm{DH}$ となった。 $\mathrm{ST}$ なりも $\mathrm{MN}$ の世帯類型の平準化率が高いのは，住宅の放熱器を同等に設定 したため, 最大熱需要に大きな差がない一方で, 平均熱需要が $\mathrm{MN}$ $>\mathrm{ST}$ なることが要因である。

\section{8 地域類型}

地域類型は世帯類型を組み合わせたもので，DHの世帯類型の割 合の高い「老朽地域」, 各断熱レベルの世帯類型を比較的均一に含 んだ「混在地域」，断熱性能の高いMN，STの世帯類型の割合が高 い「新興地域」(以下, それぞれ老朽, 混在, 新興) の 3 つを設定し た。配分割合は断熱レベルを基準に老朽でDH：80\%, MN : $10 \%$, ST : $10 \%$, 混在でDH : $40 \%, \mathrm{MN}: 30 \%$, ST : $30 \%$, 新興 でDH : $0 \%, \mathrm{MN}: 50 \%, \mathrm{ST}: 50 \%$ とし, 家族類型の群分類は各断 熱レベルに対して札幌市の人口統計を参考に配分した。

図7に各地域類型の単位需要家あたりの熱需要の分布を示す。熱 需要の最大值は $\mathrm{DH}$ の割合の大きい順に老朽 $>$ 混在 $>$ 新興となっ た。一方で老朽では最大值が約 $15 \mathrm{kWh} / \mathrm{h}$ ・件なのに対して, 暖房時 間の影響から熱需要の小さい時間も多く，4000〜 5000時間周辺で $1 \mathrm{kWh} / \mathrm{h}$ ·件を下回り, ばらつきの大きな熱需要分布となった。

図8 に各地域類型の単位需要家あたりの年積算熱需要と平準化率 の関係を示す。老朽では熱需要が約 $20 \mathrm{MWh} / \mathrm{year}$ 件と大きく, 平 準化率は約 $25 \%$ で低かった。逆に新興では熱需要が約 $11 \mathrm{MWh} /$ year・件で最も小さく, 平準化率は約 $37 \%$ で最も高かった。混在で は熱需要が約 $16 \mathrm{MWh} / \mathrm{year} \cdot$ 件，平準化率は約 $30 \%$ でり，概ね老 朽と新興の中間に位置した。

表2 各断熱レベルの断熱仕様

\begin{tabular}{|c|c|c|c|}
\hline & 老朽住宅 (DH) & ミニマムレベル(MN) & スタタダードレベル (ST) \\
\hline 天井 & GW7゙ロ-13K $100_{\mathrm{mm}}$ & GW7゙ロ-13K 300 $\mathrm{mm}$ & GWブロ-13K 400 $\mathrm{mm}$ \\
\hline 断熱什样 外壁 & GW13K $100_{\mathrm{mm}}$ & HGW16K $100_{\mathrm{mm}}$ & HGW16K $100+100_{\mathrm{mm}}$ \\
\hline 洋5) 床 & GW13K $100_{m}$ & なし & なし \\
\hline 空 & 複層ガラス & Low-E複層 & アルゴンLow-E複層 \\
\hline 基礎 & なし & XPS $50_{\mathrm{mm}}$ & XPS $50+50_{\mathrm{mm}}$ \\
\hline 換気方式 & 第3種換気 & パツシブ換気 & パツシブ換気 \\
\hline $\mathrm{UA}$ 值 $\left[\mathrm{W} / \mathrm{m}^{2} \mathrm{~K}\right]$ & 0.65 & 0.45 & 0.27 \\
\hline $\mathrm{Q}$ 値 $\left[\mathrm{W} / \mathrm{m}^{2} \mathrm{~K}\right]$ & & & 0.99 \\
\hline 換気回数 注4) & & 5 回/h & 0.35 回 $/ \mathrm{h}$ \\
\hline 暖房時間 & \begin{tabular}{c|} 
間欠暖房 \\
(睡眠時除く在宅時の \\
み暖房)
\end{tabular} & \multicolumn{2}{|c|}{ 連続暖房(24時間) } \\
\hline 設定温度 & $\begin{array}{c}22^{\circ} \mathrm{C} \\
\text { (起床2時間前から暖 } \\
\text { 房開始) }\end{array}$ & \multicolumn{2}{|c|}{$\begin{array}{r}\text { 居室(在室時): } 22^{\circ} \mathrm{C} \text { (在宅時, 睡眠時除く) } \\
18^{\circ} \mathrm{C} \text { (不在時, 睡眠時) } \\
\text { 非居室または居室 (非在室時): } 18^{\circ} \mathrm{C}\end{array}$} \\
\hline その他 & 全室暖房, 暖房! & 圕1 & 放熱器容量 $18 \mathrm{~kW}$ \\
\hline
\end{tabular}

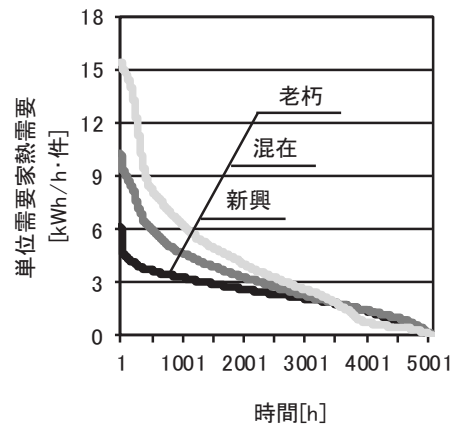

図7 各地域類型の熱需要の分布

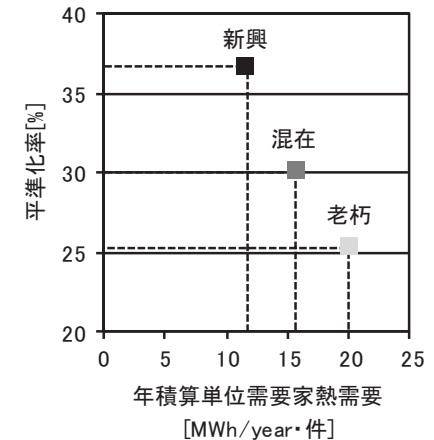

図8各地域類型の熱需要と平準化率 
3. システム検証

3.1 コミュニティ暖房のモデル化

本章では前章で作成した地域の熱需要を基に, 各種パラメータが システム効率に及ぼす影響を明らかにする。図 9 にコミュニィ暖 房システムのモデル概念図を示す。熱源であるバイオマスボイラー に一次ポンプを合わせてエネルギーセンターと定義し，そこで製造 した熱を温水として地中に埋設された熱導管を経由して各需要家に 供給する。エネルギーセンターが製造する熱を「製造熱量 $\left.E_{\text {product }}\right\rfloor$ とし，そのうち各需要家が住宅内の設定室温を維持するのに用いた 熱 (=熱需要)を「利用熱量 $\left.E_{l o a d}\right\rfloor$, 熱導管内を流れる温水から地中 に逃げる熱を「損失熱量 $\left.E_{\text {loss }}\right\rfloor$ と定義した。また，各需要家に供給 された熱のうち, 設定室温を超えて過剩に供給された熱を「余剩熱 量 $E_{\text {excess }} 」$ とた。以上 $4 つ の$ 熱量には下記の関係が成り立つ。

$$
E_{\text {product }}=E_{\text {load_all }}+E_{\text {loss_all }}+E_{\text {excess }}
$$

$E_{\text {load_all }}$ は各需要家における利用熱量の和， $E_{\text {loss_all }}$ は各単位熱導管 の損失熱量の和を表し, 下記のように求められる。

$$
\begin{aligned}
E_{\text {load_all }} & =\sum_{j=1}^{N_{p}} \sum_{k=1}^{N_{h}(j)} E_{\text {load }}(j, k) \\
E_{\text {loss_all }} & =\sum_{j=1}^{N_{p}} \sum_{k=1}^{N_{h}(j)}\left\{E_{\text {loss_s }}(j, k)+E_{\text {loss_r }}(j, k)+E_{\text {loss_b }}(j, k)\right\}
\end{aligned}
$$

単位熱導管注6) $の$ 損失熱量 $E_{\text {loss_element }}(j, k)$ は管内温度 $T_{e}$ と外気温 $T_{o}$ との関係から温水一外気の合成熱抵抗 $R_{\text {element }}(j, k)$ 注7) を用いて下 記のように求められる。

$$
E_{\text {loss_element }}(j, k)=c \rho V_{\text {element }}(j, k)\left(T_{\text {element_1 }}(j, k)-T_{o}\right)
$$

$$
\left(1-e^{-\frac{L}{c \rho V_{\text {element }}(j, k) R_{\text {element }}(j, k)}}\right)(4)
$$

余剩熱量 $E_{\text {excess }}$ は利用熱量及び損失熱量分の熱量を製造した際の ボイラー出力が最低出力を下回る場合における, その差分の熱量と して定義した。利用熱量と損失熱量の和とボイラーの最低出力の関 係によって下記のように求められる。

$$
\begin{aligned}
& \text { i) } E_{\text {load }}+E_{\text {loss }}>W_{\text {boiler_min }} \text { のとき } \\
& E_{\text {excess }}=0
\end{aligned}
$$

ii ) $E_{\text {load }}+E_{\text {loss }}<W_{\text {boiler_min }}$ のとき

$E_{\text {excess }}=W_{\text {boiler_min }}-\left(E_{\text {load_all }}+E_{\text {loss_all }}\right)$

ボイラーから延びる往き管・還り管一組を 1 系統とし, 熱導管(片

道) を $8 \mathrm{~m}$ 延長させるごとに接続する需要家が 1 件増えると仮定し た。断熱を施した熱導管はポリエチレン管とし，管内流速は1.0〜
$2.0 \mathrm{~m} / \mathrm{s}$ とした。各単位熱導管は最大流速を満たす最小の導管径を選 択した。ポンプは変流量方式を採用した注8)。

地域の世帯構成は全件数に対して各地域類型で決めた各世帯類型 の割合に応じて配分し，エネルギーセンターから断熱レベルDH,

MN，STの順に配置した。なお，家族類型の群分類は断熱レベルが 同じグループ内でランダムに配置した。

バイオマスボイラーは設定した地域の最大熱需要の $120 \%$ を定格 出力とし, 最低出力は定格出力の $25 \%$ とした。また, 近年のバイオ マスボイラーの性能向上によってボイラー効率は負荷率にほとんど 影響を受けず，高効率を維持できるようになった。これを考慮し， ボイラー効率 $\eta_{\text {boiler }}$ は負荷率に依らず 0.85 で一定とした。

以降の解析ではバイオマスを用いた熱供給の事例を参考に, 需要 家件数 40 件, 系統数 2 , 断熱厚さ $30 \mathrm{~mm}$, ボイラー数 1 台の条件を 標準モデルとし，特に断りがない限りこの条件で計算を行った。

\section{2 評価指標}

本研究では, システムの評価は基本的に一次エネルギーを基準し て行う。コミュニティ暖房システムに投入される一次エネルギーは チップボイラーに投入される木質チップの製造・搬送時に要するエ ネルギー $P E_{\text {boiler }}$, ボイラー補機動力 $P E_{\text {aux }}{ }^{\text {i⿱ } 9)}$ ， ポンプ動力 $P E_{\text {pump }}$ 主 10)によって構成される。なお, 日本では, 木質チップの一次エネ ルギーは0として扱われるが，今回は木質チップ製造・運搬に要す る化石燃料の一次エネルギーを評価するために，木質チップの燃焼 熱量にドイツ工業規格で定められている自国生産した際の木質チッ プの一次エネルギー換算係数 (PEF (Primary Energy Factor)) $F_{p e}=0.2$ を乗じることで求めた。また, ボイラー補機動力, ポンプ 動力は消費電力を発電効率 (系統電力の受電端効率) $\eta_{g_{s}}$ で除するこ とで求めることができる。下記に計算式を示す。

$$
\begin{aligned}
& P E=P E_{\text {boiler }}+P E_{\text {aux }}+P E_{\text {pump }} \\
& P E_{\text {boiler }}=\frac{E_{\text {product }}}{\eta_{\text {boiler }}} F_{\text {pe }} \\
& P E_{\text {aux }}=\frac{W_{\text {aux }}}{\eta_{g s}} \\
& P E_{\text {pump }}=\frac{\sum_{j=1}^{N_{p}} W_{\text {pump }}(j)}{\eta_{g s}}
\end{aligned}
$$

また, コミュニティ暖房システムの評価指標である一次エネル ギー基準のシステム効率 $S C O P$ は利用熱量の和 $E_{\text {load_all }}$ をシステムに 投入される全一次エネルギーPEで除することで求められる。

$$
S C O P[-]=\frac{E_{\text {load_all }}}{P E_{\text {boiler }}+P E_{\text {aux }}+P E_{\text {pump }}}
$$
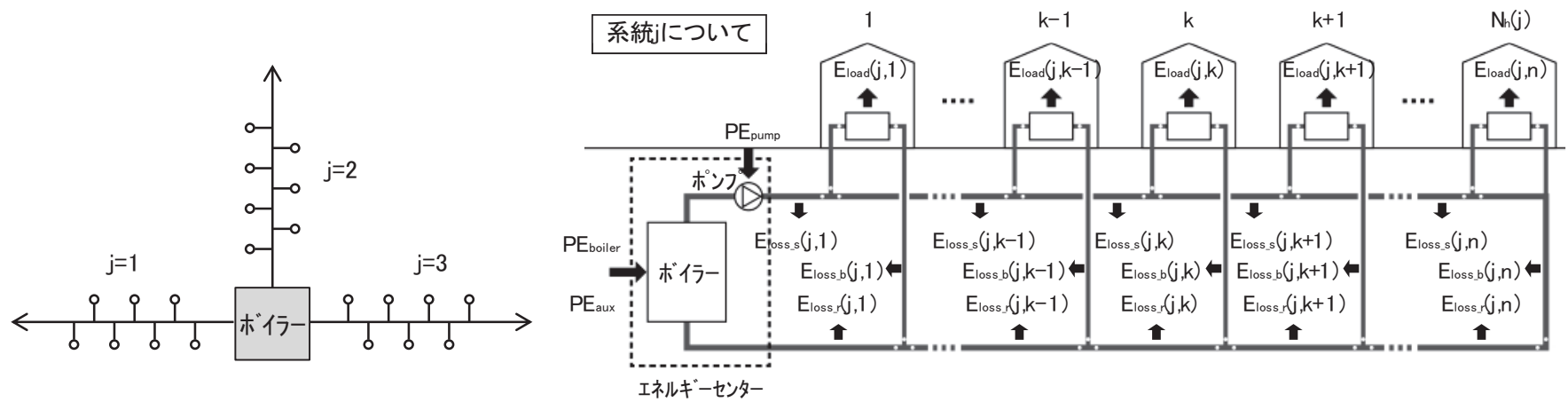

図9コミュニティ暖房のモデル概念図 


\section{3 月別製造熱量の内訳}

図10に各地域類型の標準モデルについて月別製造熱量の構成を 示す。損失熱量は全地域類型で外気温の低くなる1月に最も大きく なり，年間では利用熱量の大きい順に老朽 $>$ 混在 $>$ 新興となった。 余剩熱量は平準化率の小さい順に老朽 $>$ 混在 $>$ 新興となった。損失 率注12) は利用熱量が大きい地域類型ほど相対的に損失熱量の割合が 小さくなり，平均で老朽が約 $11 \%$ ，混在が約 $14 \% ，$ 新興が約 $19 \%$ で あった。

\section{4 コミュニティサイズの検討}

次にコミュニティ暖房において熱源を共有する地域(コミュニ ティ)のサイズの検討を行う。本研究ではコミュニティのサイズを 需要家件数によって表している。図11に系統数 1 , 断熱厚さ $30 \mathrm{~mm}$ における需要家件数と一次エネルギー使用量の関係を示す。木質 チップ製造・運搬に要するエネルギーおよびボイラー補機動力が需 要家件数に対して比例的に増加した一方で，ポンプ動力は加速度的 に増加した。これは需要家の増加に伴い温水の流量が増大寸ると同 時に, 熱需要に応じて熱導管の導管径が最小になるように選定し, 圧力損失が増したことが要因である。これより, 需要家件数の増加 に伴ってポンプ動力が支配的になり, 老朽, 混在, 新興それぞれの 全体に占めるポンプ動力の割合は仮に 20 件では約 $11.0,13.5$, $13.7 \%$ となり，100件では約 $20.6 ， 24.9 ， 25.4 \%$ と上昇した。

図12 に需要家件数と $S C O P$ 関係を示す。SCOPは全需要家件数 で新興〉混在＞老朽となった。SCOPが単純減少したのは，全需要 家件数で世帯類型の配分割合が同じであるため, 需要家件数の増加 に伴って平準化率が向上しないことが原因である。一次エネルギー では，木質チップ自体の持つポテンシャルが評価されず，相対的に ポンプ動力の割合が高くなる。よって，木質バイオマスを用いたコ ミュニティ暖房システムでは, 小さなコミュニティサイズでシステ ムを構築することが $S C O P$ 向上に有効と考えられる。また，個別暖
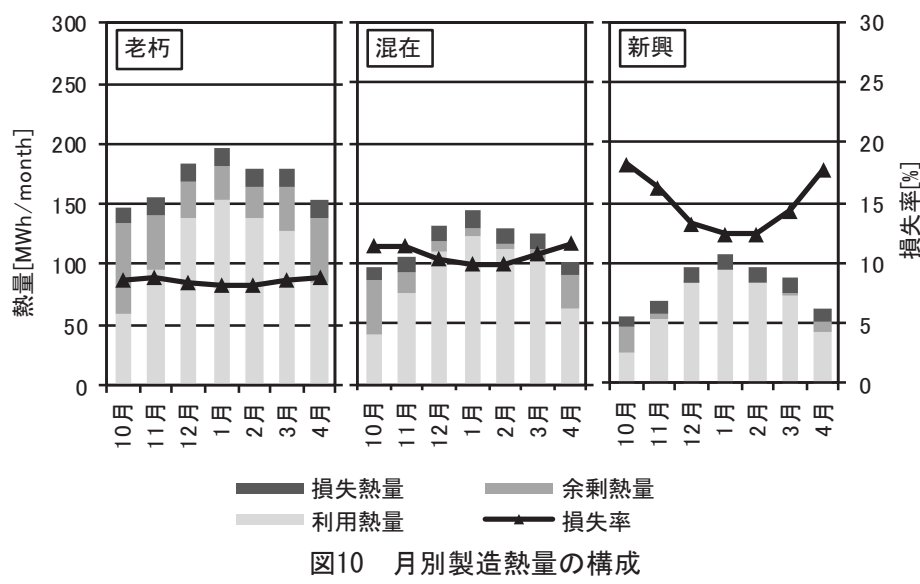

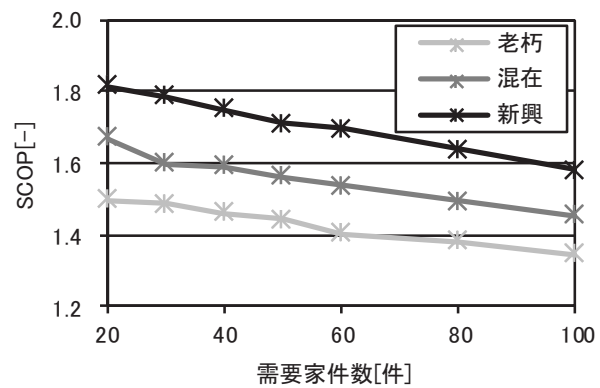

図12 需要家件数とSCOP

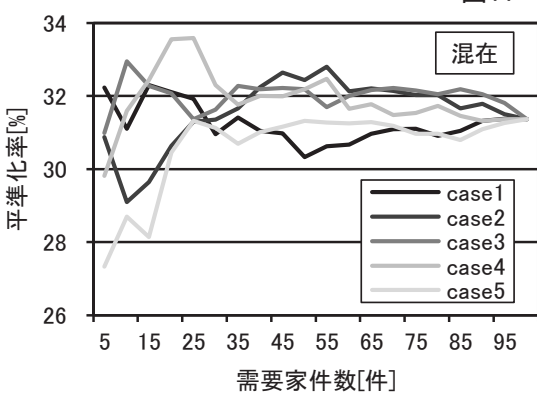

図13 需要家件数と平準化率
房であるヒートポンプ式温水暖房機の暖房効率を 1.7 とすると，一

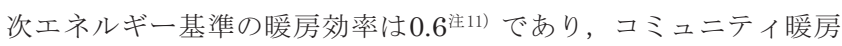
のSCOPは全地域類型および需要家件数でこれを上回った。

次に需要家件数と平準化率の関係を把握するため, 混在の需要家 を100件 (DH40件，MN30件，ST30件)とし，これを断熱レベルに 関わらず，ランダムに並べた5ケースに対象に，エネルギーセン ターに近いものから5件ずつ接続した際の平準化率の変化を見た。 図13に需要家件数と平準化率の関係を示す。平準化率は接続され た住宅の断熱性能に大きく影響を受け, 需要家件数の増加に対して 向上しないケースが多く見られた。これより，住宅のみを対象とし たコミュニティ暖房では平準化率の向上に繋がるスケールメリット を得るのが困難であり，学校施設や高齢者施設などの特に日中に熱 需要が大きい用途建物を組み込むことが有効と考えられる。

図14に需要家件数とバイオマスボイラーに投入される年積算木 質チップ量の関係を示す。ここでは，国内事例13）を参考に，カラ マツとトドマツの木質チップを用いた場合について検討した。な お，含水率は $45 \%$ ，発熱量は $9.2 \mathrm{MJ} / \mathrm{kg}$ として計算した。年積算木 質チップ投入量は需要家件数に対して比例的に増加し, 需要家件数 40件を見ると，老朽，混在，新興それぞれで約 $553 ， 387 ， 269 \mathrm{ton} /$ yearとなった。また，一日あたりそれぞれ平均で $2.6 ， 1.8 ， 1.3 \mathrm{ton} /$ day, 最大で $3.6,2.8,2.2$ ton/dayであった。

\section{5 需要家の配置の影響}

標準モデル (需要家 40 件 (DH16件，MN12件，ST12件))で系統 数1の条件について, ランダムに並べた DH住宅群およびMN $+\mathrm{ST}$ 住宅群に対して，DH住宅群をエネルギーセンターから 1～16, 13 〜28，25〜 40件目に配置した際のSCOPの推移を図15に示す。損 失熱量はDH住宅群がエネルギーセンターから離れるに伴って増大 したが，ポンプ動力は減少した。これは熱導管の最適設計を行った 場合，DH住宅群が近いほど全体の導管径が小さくなり，圧力損失
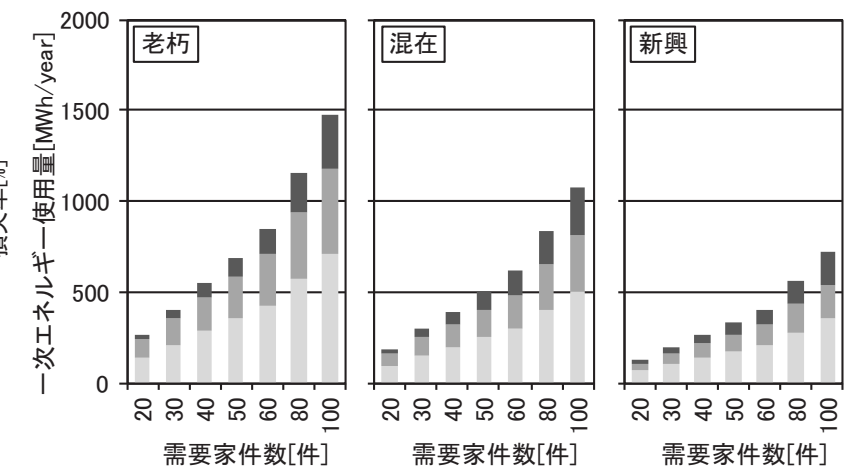

ㅇํㅇ유용요 需要家件数 $[$ 件 $]$

ロ電力 (ポンプ) ロ電カ(ボイラー補機) 木質チップ製造·運搬に要するエネルギー

図11 需要家件数と一次エネルギ一使用量の構成

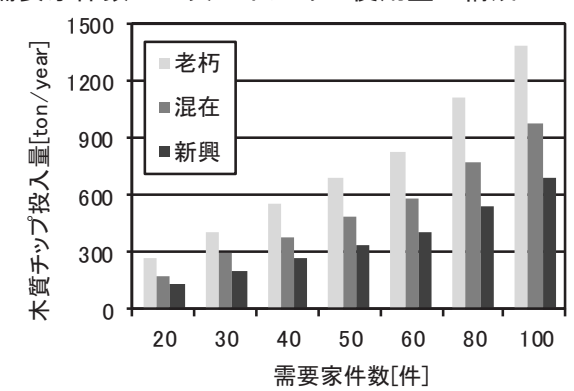

図14＼cjkstart需要家件数と木質チップ投入量 
の増大による影響が大きくなることが原因と考えられる。

SCOPはポンプ動力と相反することから，一般的な熱需要の大き な建物周辺にエネルギーセンターを配置する計画では, 損失熱量や 熱導管の敷設コストを縮減できる一方で, ポンプ動力が増大し, シ ステムとしての効率低下の危険性が示唆された。

\section{6 各種省エネ方策の効果}

コミュニティ暖房の省エネ化の方策として「台数制御の導入 (ボ イラー数の増加)」, 「系統数の増加」，「熱導管の断熱厚さの増 加」の3つを挙げ，それぞれの効果を検証した。台数制御では, 最 適制御の計算は行わず，利用熱量と損失熱量の和に対して稼働中の ボイラーの定格出力の和を上回った際に新たにボイラーを 1 台稼働 し，上回った差分を負担する簡潔な制御とした。

図16に標準モデルを基準とする各種省エネ方策の効果を示す。3 つの方策のうち, 全地域類型で系統数の増加による効果が最も大き く, 一次エネルギー使用量に占める割合の大きいポンプ動力の削減 に効果的であった。また，ボイラーの台数制御は平準化率の低い老 朽で最も効果が大きく, 熱導管の断熱厚さは損失熱量の低減に大き な効果があったが，SCOPに対する効果としては比較的小さかっ た。混在, 新興において, ボイラー数 2 台よりも 3 台のSCOPが小さ くなるのは, ボイラー1台あたりの最低出力が小さくなることで, 熱需要の小さい時間の余剩熱量が削減される一方で, それ以外の熱 需要に対して余剩熱量が発生する時間が増大するためである。

\section{7 エクセルギー消費過程}

一次エネルギー評価では，木質チップ自体の持つポテンシャルが 評価されないが，エクセルギーの概念の導入によって，木質チップ を化石燃料と同等に見なしての評価が可能となる注13)。本節では, 個別暖房 (ヒートポンプ式温水暖房機) とエクセルギー消費過程を比 較し，バイオマスを用いたコミュニティ暖房の特性を見た注14)。

図17に標準モデルにおけるコミュニティ暖房と個別暖房のエク

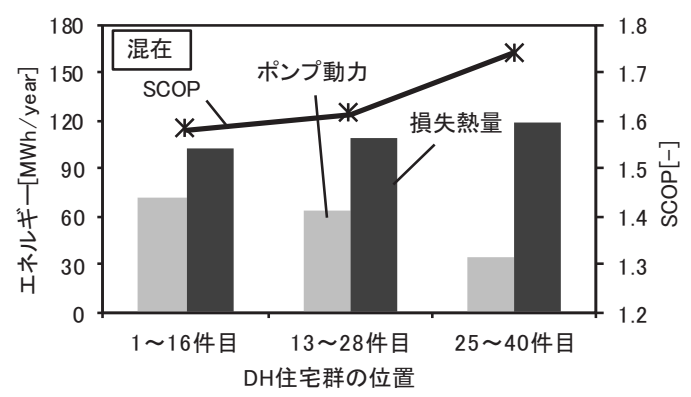

図15 DH住宅群の位置とSCOP

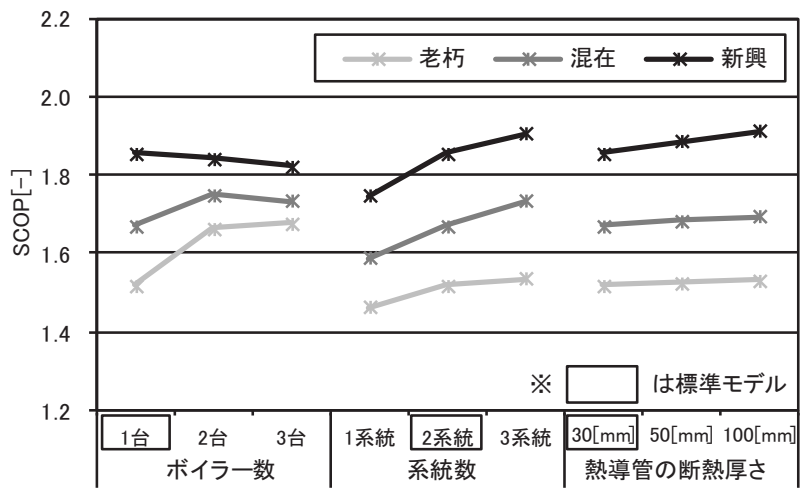

図16 各種省エネ方策の効果
セルギー消費過程を示す注15)。混在地域を見ると，コミュニティ暖 房では，267kWのエクセルギーを持つ木質チップ及び化石燃料が システムに投入され，まず木質チップの製造・運搬過程及び発電所 で $61 \mathrm{~kW}$ が消費される。次にボイラー及びボイラー補機，ポンプで $176 \mathrm{~kW}$, 熱導管で $7 \mathrm{~kW}$, 熱交換器で $5 \mathrm{~kW}$ が消費され, さらに $18 \mathrm{~kW}$ 焦戸内を循環する冷媒に入力される。その後, パネルヒー ター，室内空気，建築外皮ですべて消費される。個別暖房では， $219 \mathrm{~kW}$ がシステムに投入され, 発電所で $142 \mathrm{~kW}$ が消費される。次 にヒートポンプ式温水暖房機で $59 \mathrm{~kW}$ が消費され。その後は，コ ミュニティ暖房と同じく $18 \mathrm{~kW}$ が冷媒に入力され，パネルヒー ター, 室内空気, 建築外皮ですべて消費される。全地域類型でシス テムに投入されるエクセルギーはコミュニティ暖房が個別暖房を上 回り，老朽で約 1.4 倍，混在で約 1.2 倍，新興で約 1.1 倍となった。 しかし，混在地域を見ると，コミュニティ暖房ではシステム全体に

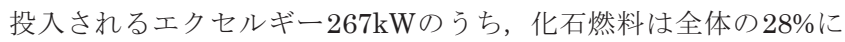

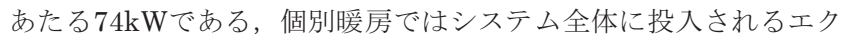
セルギー $219 \mathrm{~kW}$ は寸べて化石然料で賄われたことがわかる。コ ミュニティ暖房では投入エクセルギーは個別暖房を上回るが，その うち化石燃料のエクセルギー $74 \mathrm{~kW}$ は個別暖房の $34 \%$ に相当し，エ ネルギー自給, 化石燃料の使用量削減という観点から, 有効なシス テムであると言える。

\section{4. 総括}

本研究により，得られた知見を以下に示す。

1）居住者の生活パターン及び住宅の断熱性能を考慮して, 新興, 混在, 老朽の3つの地域類型における熱需要を作成した。老朽は熱 需要が大きく, 平準化率が低かった。逆に新興は熱需要が小さく, 平準化率が高かった。混在は概ね老朽と新興の中間に位置した。

2）SCOPは需要家件数 $20 \sim 100$ 件の範囲では新興 $>$ 混在 $>$ 老朽の順 で大きくなり, 全地域類型および全需要家件数で個別暖房の暖房効 率を上回った。

3）今回作成した地域の熱需要では, 需要家件数の増加による平準 化率の向上によるスケールメリットがあまり見られず，住宅だけで なく，学校施設や高齢者施設などの特に日中に熱需要が大きい用途 建物を組み込むことが有効と考えられる。

4）断熱性能の低いDH住宅群をエネルギーセンター近辺に配置する と, 損失熱量は減少するものの, 全体の導管径が小さくなることで ポンプ動力は増大し，システム効率は低下した。

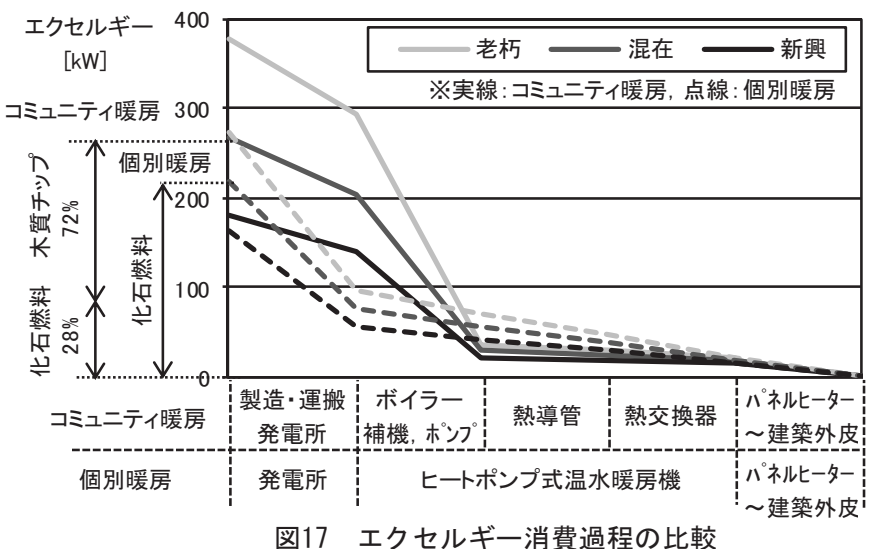

図17 エクセルギー消費過程の比較 
5）コミュニティ暖房の省エネルギー化に向けた方策の効果として は, 系統数の増加 >台数制御の導入>断熱厚さの増加となった。 6）システムに投入されるエクセルギーは全地域類型でコミュニ ティ暖房が個別暖房よりも多く必要であった。一方で，化石然料の 投入量は個別暖房を下回り，地域のエネルギー自給，化石燃料使用 量の削減という観点から有効なシステムであると言える。

\section{5. 今後の展望}

本研究では, 各種パラメータが木質バイオマスを用いたコミュニ ティ暖房のシステム効率に与える影響を明らかにした。しかし，住 宅のみを対象としたシステムでは平準化率の向上がほとんど見られ なかったため, 今後は学校施設や高齢者施設といった建物用途を含 むモデルを対象に解析を行い, コミュニティ暖房のスケールメリッ 卜を把握する必要がある。さらに，木質バイオマスを用いた小規模 熱供給の事例の多くで導入されている蓄熱槽・バックアップボイ ラーを組み込んだシステムの検討やコストを含む事業としての継続 性の評価も必要である。

\section{謝辞}

平成28３0年度科学研究費補助金 (基盤研究 (C) )「北方圈を対象之 した超高性能パッシブ換気住宅の開発」(研究代表者: 菊田弘輝)を 受けて本研究を実施しました。

注

注1）『SCHEDULE Ver.2.1』には国民生活時間調查(1995年)から作成し た生活スケジュールが組み込まれているが，今回はより実態に近い熱 需要を作成するために，国民生活時間調査 (2010年)を基に作成した 生活スケジュールを作成した。国民生活時間調查の集計は「平日」, 「土曜日」，「日曜日」について行われるのに対して『SCHEDULE Ver.2.1』では「平日」と「休日」の2つのパターンを入力することに なっているので, 「平日」には国民生活時間調査の「平日」,「休 日」には「日曜日」の情報を入力した。生活スケジュールの作成手順 はソフト取り扱い説明書に記載されている方法に準拠した。

注2）人体発熱量, 照明発熱量は初期值を使用した。また, 機器発熱量につ いては，「高齢単身」や「高齢夫婦」の形式の家族類型で旧型の家電 を使用するなどの偏りがあることが予想されるが，今回の解析結果全 体への影響は軽微であると判断し, 初期值を使用した。なお, この初 期值は10数年前の機器性能相当であり, 現在販売されている機器の性 能を考慮すると機器発熱量が小さくなることが考えられる。家族類型 を構成する各属性が使用する部屋は「単独」世帯及び「夫婦」世帯の 場合は個室 1 に,「親十子」世帯は親を個室 1 に，子は年長者から一人 ずつ個室2，3の順で割り当てた。

注3）注表1に本研究で検討した家族類型及び属する群分類を示す。同一形 式内では概初群分類は同じであることがわかる。群分類の分配割合は 全断熱レベルで同じとし，札幌市の人口統計から算出した家族形式の 割合を用いて，群分類1を $18.8 \% ， 2$ を $30.7 \% ， 3$ を $25.2 \% ， 4$ を $0.0 \%$ ，5を $12.6 \% ， 6 を 12.6 \%$ とした。また，本モデルでは戸建住宅を想定してい ることを考慮して,「男勤め人」，「女勤め人」による単独世帯を含 む家族類型の群分類 4 を $0 \%$ としたことに留意する。

注4）平準化率は下記の式から求められる。

$$
\text { 平準化率 }[\%]=\frac{\text { 時刻別平均熱需要 }[\mathrm{Wh} / \mathrm{h}]}{\text { 時刻別最大熱需要 }[\mathrm{Wh} / \mathrm{h}]} \times 100
$$

注5） $\mathrm{DH}$ 断熱仕様及び換気回数は参考文献15）における「無落雪屋根の 住宅」を参考に設定した。また，MN，STは断熱仕様は参考文献16) を，換気回数は参考文献17）の実測值を参考に設定した。

注6）単位熱導管は各需要家により区切られる熱導管の区間と定義した。同 一単位熱導管内で導管径は変わらず，そのうち往き管に分類されるも のを単位往き管，還り管を単位往き管，枝管を単位枝管とした。
注7）注図1に単位熱導管の断面モデルを示す。単位熱導管を流れる温水と 外気の間の合成熱抵抗 $R_{\text {element }}(j, k)$ は温水々熱導管表面の熱抵抗 $R_{1 \_e l e m e n t}(j, k)$, 熱導管の熱抵抗 $R_{2}$ element $(j, k)$, 断熱材の熱抵抗 $R_{3 \_ \text {element }}(j, \mathrm{k})$ ，土鎄熱抵抗および地表面と外気の熱抵抗の合成熱抵抗 $R_{\text {_element }}(j, \mathrm{k})$ によって構成され，それぞれ下記の式から求められる。

$R_{\text {element }}(j, k)=R_{1_{-} \text {element }}(j, k)+R_{2_{-} \text {element }}(j, k)$

$$
\begin{aligned}
& +R_{3 \_ \text {element }}(j, k)+R_{4 \_ \text {element }}(j, k) \\
R_{1 \_ \text {element }}(j, k) & =\frac{1}{2 \pi r_{1 \_ \text {element }}(j, k) \alpha_{i}} \\
R_{2 \_ \text {element }}(j, k) & =\frac{1}{2 \pi \lambda_{\text {pipe }}} \operatorname{In} \frac{r_{2 \_ \text {element }}(j, k)}{r_{1 \_ \text {_element }}(j, k)} \\
R_{3 \_ \text {element }}(j, k) & =\frac{1}{2 \pi \lambda_{\text {ins }}} \operatorname{In} \frac{r_{3 \_ \text {element }}(j, k)}{r_{2 \_ \text {element }}(j, k)} \\
R_{4 \_ \text {element }}(j, k) & =\frac{1}{2 \pi \lambda_{\text {soil }}} \operatorname{In} \frac{2 h^{\prime}}{r_{3 \_ \text {element }}(j, k)}
\end{aligned}
$$

ただし，相当埋設深さ $h^{\prime}$ は地表面から熱導管の中心までの長さであ る埋設深さ $h$ を用いて下記の式から求められる。

$$
h^{\prime}=h+\frac{\lambda_{\text {soil }}}{\alpha_{o}}
$$

\begin{tabular}{|c|c|c|c|}
\hline 番号 & 形式 & 家族類型 & 群分類 \\
\hline 1 & \multirow{2}{*}{ 若年夫婦 } & 男勤め人＋女勤め人 & 5 \\
\hline 2 & & 男勤め人+主婦 & 2 \\
\hline 3 & 高齢夫婦 & 男70歳以上十女70歳以上 & $2 *$ \\
\hline 4 & \multirow{5}{*}{$\begin{array}{c}\text { 夫婦 (共働き) +子 } \\
\times 1\end{array}$} & 男勤め人＋女勤め人＋小学生 & 5* \\
\hline 5 & & 男勤め人+女勤め人+中学生 & 5 \\
\hline 6 & & 男勤め人十女勤め人＋高校生 & 5 \\
\hline 7 & & 男勤め人十女勤め人＋男勤め人 & 5 \\
\hline 8 & & 男勤め人＋女勤め人＋女勤め人 & 5 \\
\hline 9 & \multirow{8}{*}{$\begin{array}{c}\text { 夫婦 (共働き) +子 } \\
\times 2\end{array}$} & 男勤め人＋女勤め人＋小学生＋小学生 & 5 \\
\hline 10 & & 男勤め人+女勤め人+小学生+中学生 & 6 \\
\hline 11 & & 男勤め人＋女勤め人＋中学生＋中学生 & 6 \\
\hline 12 & & 男勤め人＋女勤め人＋中学生＋高校生 & $6 *$ \\
\hline 13 & & 男勤め人十女勤め人+高校生+高校生 & 6 \\
\hline 14 & & 男勤め人＋女勤め人＋男勤め人＋男勤め人 & 6 \\
\hline 15 & & 男勤め人＋女勤め人＋女勤め人＋女勤め人 & 6 \\
\hline 16 & & 男勤め人＋女勤め人＋男勤め人＋女勤め人 & 6 \\
\hline 17 & \multirow{5}{*}{ 夫婦 $\left(\begin{array}{c}\text { 主婦 })+子 \times \\
1\end{array}\right.$} & 男勤め人+主婦+小学生 & 3 \\
\hline 18 & & 男勤め人+主婦＋中学生 & 3 \\
\hline 19 & & 男勤め人+主婦＋高校生 & 3 \\
\hline 20 & & 男勤め人+主婦＋男勤め人 & 3 \\
\hline 21 & & 男勤め人＋主婦＋女勤め人 & 3 \\
\hline 22 & \multirow{8}{*}{$\begin{array}{c}\text { 夫婦 }(\text { 主婦) }+ \text { 子× } \\
2\end{array}$} & 男勤め人＋主婦＋小学生＋小学生 & 3 \\
\hline 23 & & 男勤め人＋主婦＋小学生＋中学生 & 3 \\
\hline 24 & & 男勤め人＋主婦＋中学生＋中学生 & 3 \\
\hline 25 & & 男勤め人＋主婦＋中学生＋高校生 & $3 *$ \\
\hline 26 & & 男勤め人+主婦十高校生+高校生 & 3 \\
\hline 27 & & 男勤め人＋主婦＋男勤め人＋男勤め人 & 3 \\
\hline 28 & & 男勤め人＋主婦＋女勤め人＋女勤め人 & 3 \\
\hline 29 & & 男勤め人＋主婦＋男勤め人＋女勤め人 & 3 \\
\hline 30 & \multirow{2}{*}{ 若年単身 } & 男勤め人 & 4 \\
\hline 31 & & 女勤め人 & $4 *$ \\
\hline 32 & \multirow{2}{*}{ 高齢単身 } & 男70歳以上 & 1 \\
\hline 33 & & 女70歳以上 & $1 *$ \\
\hline
\end{tabular}

また，熱導管内側表面の熱伝達率 $a_{i}$ は管内温度 $T_{e}$, 管内流速 $v$, 導管 径 $d$ を用いて下記の式から求められる。

$$
\alpha_{i}=\frac{\left(1663+24 T_{e}\right) v^{0.8}}{d^{0.2}}
$$

注表1 家族類型の一覧

※「*」は群分類を代表する家族類型を示す。

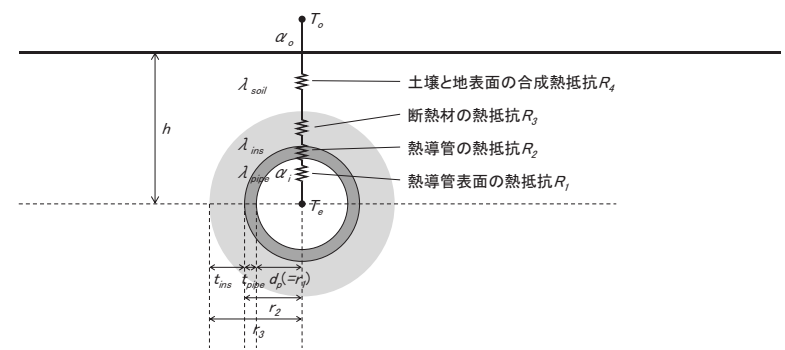

注図1 単位熱導管断面モデル 
解析では総合熱伝達率 $\alpha_{i}$ による $R_{1}(j, k)$ の変動が十分小さいことを確 認したうえで, 管内温度 $T_{e}=60^{\circ} \mathrm{C}$, 管内流速 $v=1.5 \mathrm{~m} / \mathrm{s}$, 導管径 $d=12.5 \mathrm{~mm}$ として計算した。

注8）温水が住戸内に入る直前の枝管の管内温度と住宅から出た直後の管内 温度の温度差 $\Delta T$ を $5 \mathrm{~K}$ と仮定した。ただし，管内流速が最低流速を下 回る場合には，管内流速を最低流速に再設定し，温度差を変動させ た。これより, 温度差 $\Delta T$ は下記の式から求められる。

$v_{b}(j, k)>=v_{\min }$ のとき

$$
\Delta T=5
$$

$V_{b}(j, k)<V_{\min }$ のとき

$$
\Delta T=\frac{E_{\text {load }}(j, k)}{c \rho \pi d_{b}(j, k)^{2} v_{\text {min }}}
$$

注9） ボイラー補機の出力 $W_{\text {aux }}$ はバイオマスボイラーのカタログを参考に ボイラーの定格出力 $W_{\text {boiler_max }}$ を変数とする一次関数の回帰直線とし て表すこととした。下記に算出式を示す。

$$
W_{\text {aux }}=0.0171 W_{\text {boiler_max }}+0.3033
$$

注10） ポンプ出力 $W_{\text {pump }}(j)$ の算出方法を以下に示す。熱導管を流れる温水の レイノルズ数 $R e_{\text {element }}(j, k)$ は下記の式から求められる。

$$
R e_{\text {element }}(j, k)=\frac{v_{\text {element }}(j, k) d_{\text {element }}(j, k)}{v}
$$

$R e=4 \times 10^{3} \sim 10^{7}, \quad \varepsilon / \mathrm{d} \leqq 0.01 の$ 範囲では管摩擦抵抗係数 $C F(j, k)$ は下 記に示すムーディの式によって簡易的に求めることができる。

$$
C F_{\text {element }}(j, k)=0.0055\left\{1+\left(20000 \frac{\varepsilon}{d_{\text {element }}(j, k)}+\frac{10^{6}}{R e_{\text {element }}(j, k)}\right)^{1 / 3}\right\}
$$

コミュニティ暖房の各系統における圧力損失はダルシー・ワイス バッハの式を用い，最遠端の住戸に到達するまでの熱導管の圧力損失 を足し合わせることで求めた。なお本来は，熱導管の分岐箇所などで でさらに圧力損失が発生するが，これは熱導管の計画によって変動す ることから，本モデルでは簡易的に $L_{s}, L_{r}, L_{b}$ それぞれについて 0.5 倍分の相当導管長さを見込むこととした。算出式を下記に示す。

$$
\begin{aligned}
\Delta P(j)=\sum_{k=1}^{N_{h}(j)}\left\{p_{s}(j, k)+p_{r}(j, k)\right\}+p_{b}\left(j, N_{h}(j)\right) \\
=\sum_{k=1}^{N_{h}(j)}\left\{C F_{s}(j, k) \frac{L_{s} \times 1.5}{d_{s}(j, k)} \frac{\rho v_{s}(j, k)^{2}}{2}+C F_{r}(j, k) \frac{L_{r} \times 1.5}{d_{r}(j, k)} \frac{\rho v_{r}(j, k)^{2}}{2}\right\} \\
+C F_{b}\left(j, N_{h}(j)\right) \frac{L_{b} \times 1.5}{d_{b}\left(j, N_{h}(j)\right)} \frac{\rho v_{b}\left(j, N_{h}(j)\right)^{2}}{2}
\end{aligned}
$$

ポンプ軸力 $E_{\text {shaft }}(j)$ は質量流量m, ポンプ効率 $\eta_{\text {pump }}$, 温水の密度 $\rho$ を 用いて下記の式から求められる。

$$
E_{\text {shaft }}(j)=\frac{m \Delta P(j)}{\eta_{\text {pomp }} \rho}
$$

ポンプ出力 $W_{\text {pump }}(j)$ はポンプ軸力をモーター効率で除することで下 記の式から求められる。

$$
W_{\text {pump }}(j)=\frac{E_{\text {shaft }}(j)}{\eta_{\text {motor }}}
$$

注11）損失率は製造熱量に占める損失熱量の割合であり，下記の式から求め られる。

$$
\text { 損失率 }[\%]=\frac{E_{\text {loss_all }}}{E_{\text {product }}} \times 100
$$

注12）ヒートポンプ式温水暖房機の暖房効率は外気温によって変動するが,

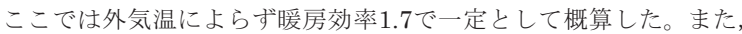
一次エネルギー基準の暖房効率は発電効率 (系統電力の受電端効率) $\eta_{g s}=0.35$ を乗じることで 0.60 とした。

注13）注図2に一次エネルギーとエクセルギーによる評価の概念図を示寸。 エクセルギーはボイラーに投入される化学エクセルギー $X_{\text {boiler }}$, ボイ ラー補機に投入される化石燃料の化学エクセルギー $X_{a u x}$, ポンプに投 入される化学エクセルギー $X_{\text {pump }}$ によて構成される。 $X_{\text {aux }}$ と $X_{\text {pump }}$ は それぞれ一次エネルギーである $P E_{\text {aux }}$ と $P E_{\text {pump }}$ に等しく, $X_{\text {boiler }}$ は木質 チップの化学エクセルギーと木質チップの製造・運搬に要する化石燃 料の化学エクセルギーの和である。

注14）コミュニティ暖房において，枝管から住戸内の熱交換器で熱交換を 行った後のプロセスは個別暖房と同じであり，熱交換器から冷媒が熱 を受け取り循環ポンプによって住戸内をめぐり，放熱器から熱が放出 される。よって熱交換器から出るエクセルギーはコミュニティ暖房と
個別暖房で同じとなる。なお，住戸内の温水循環に要する循環ポンブ の動力は個別暖房, コミュニティ暖房で同じと仮定し，評価には含ま れていない。

注15）以下に熱導管に入力されるエクセルギー $X_{p i p e}$ と熱交換器に入力される エクセルギー $X_{h e x}$, 住戸内を循環する冷媒に入力されるエクセルギー $X_{i n V}$ の計算方法を示す ${ }^{18)}$ 。ボイラーが木質チップを燃焼させることで 熱導管内の温水に入力されるエクセルギー $X_{\text {pipe }}$ は, ボイラーから出る 温水(往き温度 $60^{\circ} \mathrm{C}$ )のもつエクセルギーとボイラーに還る温水(還り 温度)のもつエクセルギーの差によって以下のように計算できる。

$$
\begin{aligned}
X_{\text {pipe }}=c \rho \sum_{j=1}^{N_{p}} V_{s}(j, 1)\{ & \left(T_{S_{-} o}(j)-T_{r_{-} o}(j)\right) \\
& \left.-\left(T_{o}+273.15\right) \log \frac{T_{S_{-} o}(j)+273.15}{T_{r_{-} o}(j)+273.15}\right\} \text { (A18) }
\end{aligned}
$$

熱交換器に入力されるエクセルギー $X_{h e x}$ も同様に熱交換器に入る温 水のもつエクセルギーと熱交換器を出るエクセルギーの差によって以 下のように計算される。

$$
\begin{array}{r}
X_{\text {hex }}=c \rho \sum_{j=1}^{N_{p}} \sum_{k=1}^{N_{h}(j)} V_{b}(j, k)\left\{\left(T_{\text {hex_in }}(j, k)-T_{\text {hex } \_ \text {out }}(j, k)\right)\right. \\
\left.-\left(T_{o}+273.15\right) \log \frac{T_{\text {hex_in }}(j, k)+273.15}{T_{\text {hex_out }}(j, k)+273.15}\right\} \quad \text { (A19) }
\end{array}
$$

熱交換器から住戸内を循環する温水に入力されるエクセルギー $X_{i n v}$ は以下の式から求められる。なお，住戸内の温水流量 $V_{\text {inv }}$ は導管径 $12.5 \mathrm{~mm}$, 管内流速 $1.0 \mathrm{~m} / \mathrm{s}$ とて計算した。熱交換器を出る温水の温 度 $T_{\text {inv_out }}(j, k)$ は $50^{\circ} \mathrm{C}$ で一定とし, $T_{\text {in__in }}(j, k)$ は各需要家の熱需要に よって変動するものとした。

$$
\begin{array}{r}
X_{i n v}=c \rho \sum_{j=1}^{N_{p}} \sum_{k=1}^{N_{h}(j)} V_{i n v}(j, k)\left\{\left(T_{i n v_{-} s}(j, k)-T_{i n v_{-} r}(j, k)\right)\right. \\
\left.-\left(T_{o}+273.15\right) \log \frac{T_{i n v_{-} s}(j, k)+273.15}{T_{i n v_{-} r}(j, k)+273.15}\right\}
\end{array}
$$

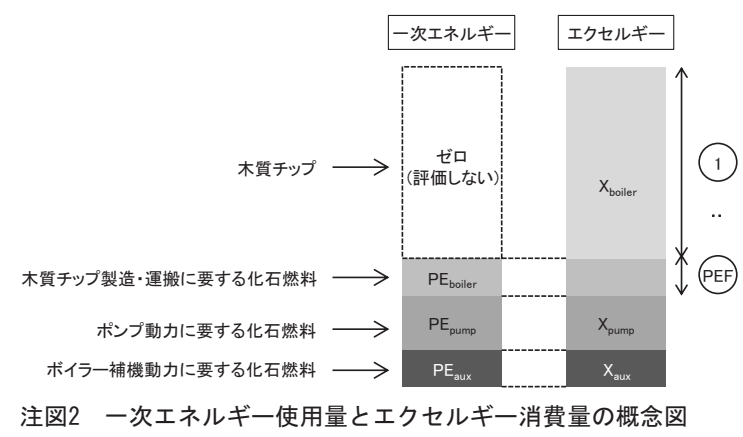

参考文献

1）北海道立北方建築総合研究所：パッシブ換気システム設計・施工マニュ アル，財団法人北海道建築指導センター, 1999.3

2）松尾悠佑，菊田弘輝，斉藤雅也，羽山広文：パッシブ換気住宅における 薪ストーブを用いた全室暖房時のエクセルギー評価, 日本建築学会環境 系論文集，No.719，pp.73-82，2016.1

3）斉藤雅也, 中原宏, 菊田弘輝 : 札幌市の全住宅の熱需要MAP作成と札幌 市南区真駒内での「次世代コミュニティ暖房」の検討, 2014.3

4）三浦秀一：第1回「欧州の再生可能エネルギーとバイオマス」，一般社 団法人日本熱供給事業協会協会誌，vol.80, pp.12-15

5）三浦秀一：第2回「地域熱供給事業における森林バイオマス利用とオー ストリアの取り組み」, 一般社団法人日本熱供給事業協会協会誌, vol.81, pp.12-15

6）三浦秀一：第3回「オーストリアにおける森林によるマイクロ地域熱供 給の取組」，一般社団法人日本熱供給事業協会協会誌，vol.82，pp.1215

7）三浦秀一：第4回「オーストリアにおける森林による地域熱供給事業の 事例と計画」，一般社団法人日本熱供給事業協会協会誌, vol.83, pp.12 $-15$

8）三浦秀一：第5回「オーストリアにおける森林エネルギー利用の展 
開」，一般社団法人日本熱供給事業協会協会誌，vol.84，pp.12-15

9) International Energy Agency : Status Report on District Heating Systems in IEA Countries, 2014.12

10) Peter Mildenstein : District Heating and Cooling Connection Handbook, IEA district heating and cooling : International Energy Agency, NOVEM(Netherlands Agency for Energy and the Environment), 2002.

11) Sven Werner : Possibilities with more district heating in Europe, Ecoheatcool and Euroheat \& Power, 2006

12）下川町：エネルギー自立と地域創造，下川町， 2014.7

13）山崎慶太, 斉藤雅也, 宿谷昌則 : 木質バイオマスを活か寸地域熱供給シ ステムのエクセルギー解析, 日本建築学会環境系論文集, No.721, pp.295-305, 2016.3

14）高橋達：下関市における木質ペレット利用コミュニティ熱供給システム の事例調査, 日本建築学会大会学術講演梗概集, 環境工学 I, pp.11851186, 2015.9

15）北方建築総合研究所 : 北海道の住宅事情と「北方型住宅」

16）一般社団法人北海道建築技術者協会：北の住まいの熱環境計画 2015 , 2015.11

17）菊田弘輝, 吉田卓生, 永沼純一, 羽山広文, 繪内正道, 阿部佑平 : 高断 熱・高気密住宅の室内環境と暖房エネルギー消費量に関する実態調査一 札幌市内の北方型住宅を対象として一, 日本建築学会環境系論文集, No.659, pp.17-24, 2011.1

18）宿谷昌則ら：エクセルギーと環境の理論, pp.204-209, 井上書院, 2010

\section{記号表}

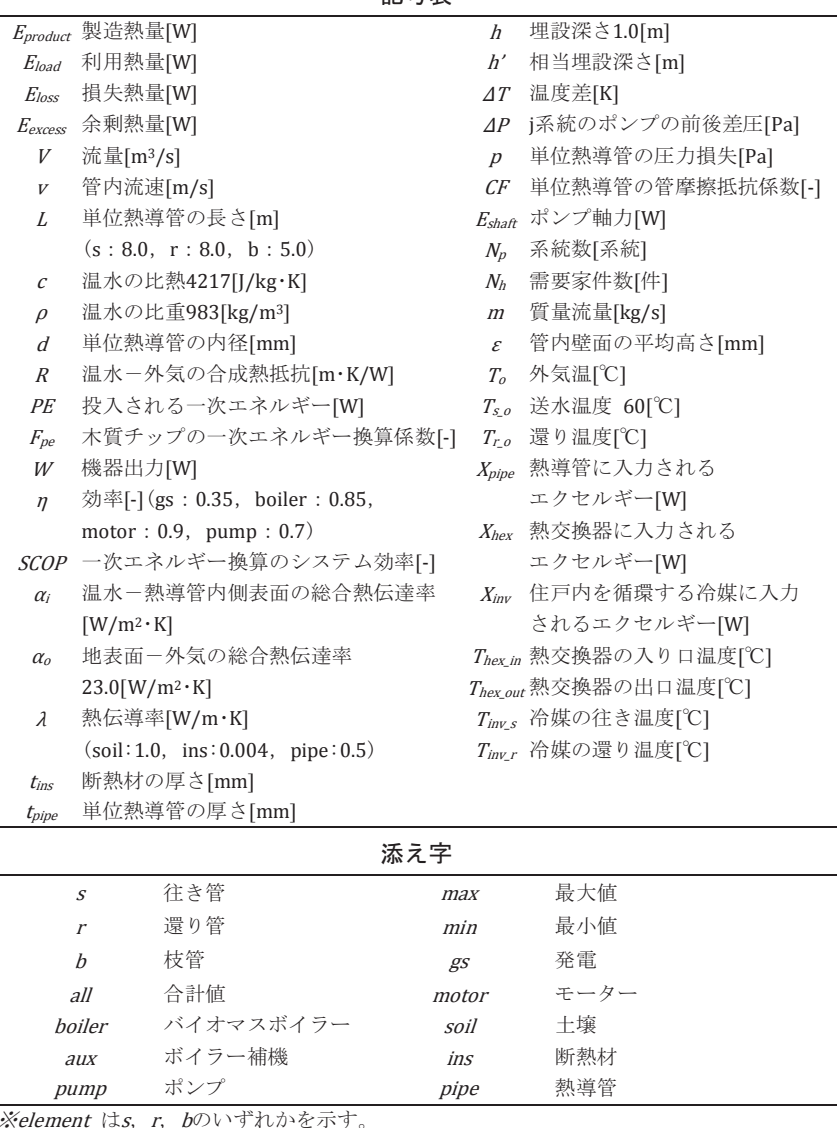

※element は $s, r, b$ のいずれかを示す。 


\title{
A STUDY ON COMMUNITY HEATING SYSTEM USING WOODY BIOMASS FOR HIGH PERFORMANCE PASSIVE VENTILATION HOUSES
}

\author{
Yusuke MATSUO* ${ }^{*}$ Koki KIKUTA**, Masaya SAITO*** \\ and Hirofumi HAYAMA**** \\ * Nihon Sekkei, Inc. \\ ** Assist. Prof., Faculty of Eng., Hokkaido Univ., Dr.Eng. \\ *** Assoc. Prof., School of Design, Sapporo City Univ., Dr.Eng. \\ **** Prof., Faculty of Eng., Hokkaido Univ., Dr.Eng.
}

\begin{abstract}
Introduction
In Hokkaido, passive ventilation system has been developed as the distinctive technology in cold region. It is essential to reduce the use of fossil fuel for space heating, therefore the planning of space heating system in high performance houses is required significant improvement of insulation as well as airtight. Over the past decades, the use of woody biomass resources for space heating and hot water supply system has been increased mainly in the mountainous areas in Japan. In some of these areas, there are "community heating system" as a small district heating system with small biomass boiler, which are consisted of some residential houses, city halls, and other public facilities. This is because woody biomass resources which can be obtained in the neighborhood mountain can contribute to reduce the use of fossil fuel and electricity. In this study from these backgrounds, we focused on how to design high-efficiency community heating system using woody biomass which supplies thermal energy to a group of high performance passive ventilation houses in a town of Hokkaido.
\end{abstract}

Analytical model of supply and demand sides in community heating system

In the past studies regarding the district heating system, a size of the heating demand has been given as the numerical values of the basic unit about the energy use according to the building types. In this study, annual heating demands of communities were assumed based on the insulation performance of houses and the living activities of households. Three types of community: new-region, mixed-region, and old-region were assumed from the combinations of three different insulation levels of houses. New-region is composed of only high insulated houses, mixed-region is mixed the low insulated with the high insulated houses, and old-region is mainly composed of low insulated houses. Annual heating demands per a household (a ratio of load levelling) were calculated $11 \mathrm{MWh} /$ year (37\%) in new-region, $16 \mathrm{MWh} / \mathrm{year}$ (30\%) in mixed-region, and $20 \mathrm{MWh} /$ year (25\%) in old-region.

On the other hand, a size of the supply side system as a biomass boiler, pumps and pipes was assumed to satisfy the peak of heating demands of the communities. The energy efficiency of a biomass boiler of $85 \%$, the insulation thickness of the polyethylene pipe lines of $30 \mathrm{~mm}$, and the flow velocity of hot water of 1.0 to $2.0 \mathrm{~m} / \mathrm{s}$ were assumed.

\section{Energy and exergy analysis of community heating system}

From the results of analysis, it was found that SCOP of community heating system tends to decrease gradually by the number of households increases despite the difference in new-region, mixed-region, and old-region. The reason is due to the fact that pump load gets larger with increasing speed. In the case of 20 to 100 households, SCOP is highest in new region, followed in order by mixed-region and old-region. SCOP in all cases of community heating system is higher than that of individual heating system. In addition, the community heating system composed of the residential houses is required a combination with some public buildings such as office school, hospital, and day-service center for the elderly which have large heating demand in the daytime. From the exergy analysis in case of 40 households, total input exergy for the community heating system were 1.1 to 1.4 times larger than that for individual heating system. However, $72 \%$ of this input exergy of the community heating system was equivalent to the chemical exergy within woody biomass which can be obtained in the neighborhood. 